\title{
Analisis Aktivitas Fisik dan Status Gizi Terhadap Kebugaran Jasmani Junior High School: Literature Review
}

\author{
Bagus Cahyono Putro, Mashuri Eko Winarno* \\ Universitas Negeri Malang, Jl. Semarang No. 5 Malang, Jawa Timur, Indonesia \\ *Penulis korespondensi, Surel: m.e.winarno.fik@um.ac.id
}

Paper received: 2-1-2022; revised: 20-1-2022; accepted: 28-1-2022

\begin{abstract}
The literature review study aims to determine the relationship between physical activity, nutritional status on junior high school students' physical fitness and related factors based on secondary data or previous research journal articles. The collection of literature review data uses the Preferred Reporting Items for Systematic Reviews and Meta-Analysis (PRISMA) flow method. Search journal articles in the review literature using methodological criteria (1) required variables (2) consistent data collection methods (3) valid research results (4) clear and precise data analysis. The results show (1) physical activity is related to physical fitness, (2) nutritional status is related to physical fitness (3) There is an insignificant relationship between physical activity and physical fitness because of the influencing factors. Conclusion: encouraging health sports and health education as a solution to physical fitness problems from physical activity factors and nutritional status. External roles are very supportive to reach the level of physical fitness such as educators and parents.
\end{abstract}

Keywords: physical activity; nutritional status; physical fitness

\begin{abstract}
Abstrak
Studi literatur review bertujuan mengetahui hubungan aktivitas fisik, status gizi terhadap kebugaran jasmani siswa SMP dan faktor yang berkaitan berdasarkan dari data sekunder atau artikel jurnal penelitian sebelumnya. Pengumpulan data literatur review menggunakan metode alir Preferred Reporting Items for Systematic Reviews and Meta-Analysis (PRISMA). Pencarian article jurnal pada literatur review menggunakan kriteria metodologis (1) variabel yang diperlukan (2) metode pengumpulan data konsisten (3) hasil penelitian valid (4) analisis data jelas dan tepat. Hasil menunjukkan (1) aktivitas fisik berhubungan terhadap kebugaran jasmani, (2) status gizi berhubungan terhadap kebugaran jasmani (3) Terdapat hubungan tidak signifikan aktivitas fisik terhadap kebugaran jasmani karena faktor yang berpengaruh. Simpulan: mendorong olahraga kesehatan dan Pendidikan kesehatan sebagai solusi permasalahan kebugaran jasmani dari faktor aktivitas fisik dan status gizi. Peran eksternal sangat mendukung untuk mencapai tingkat kebugaran jasmani seperti pendidik dan orangtua.
\end{abstract}

Kata kunci: aktivitas fisik; status gizi; kebugaran jasmani

\section{Pendahuluan}

Secara umum, pendidikan nasional memiliki beberapa fungsi, salah satunya untuk mengembangkan dan membentuk kemampuan, watak agar mampu berkembang dalam aspek spiritual, sikap dan pengetahuan. Pendidikan jasmani, olahraga, dan kesehatan (PJOK) merupakan salah satu mata pelajaran yang diajarkan di sekolah dan bertujuan selaras dengan fungsi pendidikan nasional. PJOK memiliki tujuan untuk meningkatkan kebugaran jasmani, keterampilan gerak, kemampuan berpikir, bersosial, penalaran, stabilitas emosional dan mampu menerapkan pola hidup sehat (Permendiknas No 22, 2006). Pendidikan jasmani memiliki hubungan dengan olahraga pendidikan yaitu pendidikan yang dilaksanakan secara teratur, berkelanjutan guna membentuk pengetahuan, kepribadian, keterampilan, kesehatan, dan kebugaran (Undang-undang No 3, 2005). Disebutkan kebugaran jasmani di atas, 
pendidikan jasmani sangat penting untuk memberikan solusi dari problematika yang ada. Adanya PJOK, kebutuhan manusia dapat terpenuhi, siswa sekolah sebagai sasaran dalam pelaksanaan PJOK yang masih masanya tumbuh dan berkembang serta membutuhkan pembinaan. Pendidikan Jasmani menganggap semua anak memiliki kesatuan yang tidak terpisahkan terkait kualitas fisik dan mental. PJOK sebagai bagian dari program pendidikan total mengutamakan aktivitas fisik untuk pertumbuhan dan perkembangan semua anak. Kebanyakan program pengajaran tersebut menjadi satu-satunya komponen domain pembelajaran yaitu, kognitif, afektif, dan psikomotor (Pangrazi \& Beighle, 2019). Pendidikan jasmani melibatkan aktivitas yang bermanfaat karena mengajarkan tentang berolahraga dengan aman dan efektif, replikasi yang akurat, menjelajah dan berkomunikasi, mengidentifikasi dan memecahkan masalah (Lavin, 2008). Pendidikan jasmani dapat sebagai proses belajar yang berfokus pada pengetahuan, sikap, dan perilaku relatif terhadap aktivitas fisik. Aktivitas fisik tidak sama seperti pendidikan jasmani, tetapi pada pendidikan jasmani melibatkan aktivitas fisik. Perbedaan antara pendidikan jasmani dan aktivitas fisik berupa aktivitas fisik melibatkan gerakan tubuh yang membantu meningkatkan energi pengeluaran dan tingkat kebugaran yang berkaitan dengan kesehatan. Aktivitas fisik dapat berintensitas rendah hingga tinggi tergantung olahraga dan permainan secara individu atau kelompok (Shimon, 2011). Pendidikan jasmani merupakan tahapan mendidik melibatkan aktivitas fisik guna mengembangkan intelektual dan jasmani. Mendidik diri-sendiri secara fisik dapat terjadi di dalam atau di luar sekolah, berupa formal maupun non-formal (El-Sherif, 2014). Pendidikan jasmani merupakan suatu proses seorang individu mengembangkan keterampilan fisik, mental, sosial, dan kebugaran jasmani (Lumpkin, 2014).

Berdasarkan penelitian oleh (Mashud, 2018) memaparkan bahwa indikator yang menyebabkan permasalahan dalam kebugaran jasmani dapat berupa menurunnya partisipasi siswa-siswi dalam ajang olahraga, meningkatnya pengguna narkoba dikalangan remaja. Adanya kondisi berdampak bagi kebugaran jasmani. Jika kebugaran jasmani rendah maka obesitas dan penyakit tidak menular menjadi berpotensi. Peserta didik dengan kebugaran jasmani yang baik memberikan dampak positif terhadap produktivitas belajar. Sangat penting makna kebugaran jasmani bagi peserta didik dan Pendidikan jasmani mengambil peran di dalamnya. Analisis masalah pokok dapat mengakar pada komponen PJOK seperti dari pendidik, dari murid, dari sarana dan prasarana yang ada. Komponen guru berhubungan dengan kompetensi, perangkat pembelajaran, model pembelajaran yang diterapkan. Komponen siswa berupa pemahaman secara teknik maupun secara taktis. Komponen sarana dan prasarana berupa alat dan bahan yang dibutuhkan dalam pelaksanaan pembelajaran PJOK.

Kedua komponen antara guru dan siswa memiliki keterkaitan yang cukup besar jika dilihat dari pengajaran. Secara umum, pengajaran PJOK dapat dilakukan dengan pendekatan secara teknis dan pendekatan secara taktis. Pendekatan teknis mengutamakan pada penguasaan konsep permainan. Pendekatan taktis mengutamakan pada penguasaan keterampilan sebelum menuju ke permainan sesungguhnya. Menurut (Sucipto dkk., 2019) pembelajaran Pendidikan jasmani dengan pendekatan taktis memungkinkan peserta didik aktif dalam aktivitas fisik sehingga timbul kesenangan untuk bergerak aktif. Tetapi, pembelajaran pendidikan jasmani dengan pendekatan teknis tetap berjalan karena bertujuan untuk memberikan kesadaran tentang konsep permainan sehingga mengetahui bentuk permasalahan pada pelaksanaan. 
Menurut Sceisarriya, (2017) permasalahan pelaksana PJOK adalah peralihan nilai budaya. Peralihan nilai tersebut terjadi karena kebiasaan bermula aktif bergerak menjadi pasif, terjadi disebabkan oleh kemudahan pada keseharian yang didukung oleh taraf hidup, penggunaan kemajuan teknologi, transportasi maupun komunikasi. Kebiasaan bergerak pada anak-anak maupun remaja menjadi minim dan berkurangnya aktivitas fisik di berbagai kegiatan yang berdampak negatif pada kebugaran jasmani.

Permasalahan dalam Pendidikan jasmani menjadi multidimensi, bahwasanya permasalahan yang sama dari tahun ke tahun masih belum mampu diselesaikan. Permasalahan tersebut dapat berupa minimnya kemampuan guru membelajarkan materi PJOK, fasilitas pendukung masih terbatas, kualifikasi Pendidikan guru tidak sesuai dengan bidang yang menjadi profesi bidang pelajaran, di beberapa bidang PJOK tidak berkualifikasi sebagai guru PJOK (Kanca, 2018). Guru pendidikan jasmani memiliki memiliki peran penting untuk mendorong dan memberikan pemahaman bahwa aktivitas fisik berpengaruh pada kebugaran jasmani yang dapat menunjang kebugaran jasmani. Studi menunjukkan mendorong aktivitas fisik berguna untuk mendukung kelanjutan pengembangan keterampilan motorik, pengembangan motorik di masa kanak-kanak memiliki hubungan dengan peningkatan fisik di masa remaja (Lisa dkk., 2011).

Pendidikan jasmani sebagai komponen penting yang menghasilkan beberapa sumbangsih bagi pembelajaran siswa. Pertama, pencapaian fisik harian untuk seluruh siswa. Kedua, pencapaian tingkat fisik yang dipersonalisasi kebugaran. Ketiga, pengembangan kompetensi secara beragam pada keterampilan fisik untuk memastikan keberhasilan fungsi dalam aktivitas fisik yang dapat digunakan sepanjang hayat. Keempat, mengharuskan siswa memperoleh persyaratan pengetahuan untuk menjalani gaya hidup aktif dan sehat(Ho et al., 2018).

Salah satu sasaran utama program peningkatan kebugaran jasmani adalah remaja berusia 13-15 tahun. Masa tersebut ditandai terjadinya perubahan yang cukup cepat secara fisik, psikis, dan kognitif. Aspek fisik sebagai hal yang sangat diperhatikan mengingat sebagai masa kematangan seksual dan pertumbuhan postur tubuh sehingga penampilan fisik menjadi diperhatikan. Aspek fisik dapat dikontrol dengan aktivitas fisik yang terprogram dan konsumsi asupan gizi yang seimbang. Berdasarkan penelitian siswa sekolah menengah pertama di Jawa Barat, siswa memiliki kebugaran jasmani dalam kategori baik sekali hanya 9,50 persen, kategori sedang sebesar 53,63 persen, sedangkan dalam kategori kebugaran jasmani rendah sebesar 36,87 persen (Sulistiono, 2014). Hasil tersebut menunjukkan kebugaran jasmani siswa masih banyak yang tidak memenuhi kategori sedang. Perubahan fisik, psikis, dan kognitif ini berdampak langsung pada status gizi remaja (Rahayu, 2020). Kecukupan energi diperlukan sebagai metabolisme tubuh. Energi yang diperlukan perempuan berusia 13-18 tahun sebesar 40-50 kkal/kgBB/hari. Sedangkan energi yang diperlukan laki-laki berusia 13-18 tahun energi sebesar 45-55 kkal/kg/hari (Susilowati \& Kuspriyanto, 2016).

Penulisan article review ini akan menjelaskan keterkaitan antara variabel aktivitas fisik, status gizi terhadap kebugaran jasmani serta peranannya pada setiap variabel yang berkaitan. Hasil penelitian mengenai aktivitas fisik berhubungan dengan tingkat kebugaran jasmani (Prasetyo \& Winarno, 2017). Aktivitas fisik pada waktu luang merupakan aktivitas dalam waktu individu untuk meningkatkan total pengeluaran energi harian dan hal ini sejalan dengan dorongan untuk memperoleh manfaat kesehatan atau kebugaran (Caldwell et al., 2020). 
Sedangkan hasil lain mengenai status gizi pada remaja berhubungan dengan tingkat kebugaran jasmani (Mahdiyyah \& Hidayat, 2020). Menurut Bush et al., (2020) keseimbangan dapat diperoleh jika energi yang masuk seimbang dengan energi yang dikeluarkan.

Hasil analisis khusus akan mengarah terhadap manfaat dari kebugaran jasmani pada aspek-aspek tertentu untuk membantu pelaksana PJOK mewujudkan capaian tingkat kebugaran jasmani siswa.

\section{Metode}

Rancangan studi ini menggunakan metode literatur review. Studi literatur review merupakan desain penelitian yang menggunakan data sekunder dengan berkaitan pada topik tertentu. Studi literatur review bertujuan untuk menyimpulkan teori dari beberapa hasil penelitian sebelumnya. Metode pengumpulan data article review ini menggunakan akses google scholar untuk artikel jurnal penelitian nasional dan artikel jurnal penelitian internasional. Akses Eric journal untuk artikel jurnal penelitian internasional. Tahap pengumpulan data pada literatur review menggunakan metode alir Preferred Reporting Items for Systematic Reviews and Meta-Analysis (PRISMA). Pencarian jurnal penelitian ditentukan pada kriteria (1) variabel sesuai dengan kebutuhan tuliskan (2) metode pengumpulan data konsisten (3) hasil penelitian diukur valid (4) analisis data didefinisikan secara jelas dan tepat. Desain penelitian yang dipilih berupa korelasional, Search terms yang digunakan ("aktivitas fisik", "status gizi" terhadap "kebugaran jasmani" "siswa smp", relationship between "physical activity", "nutritional status" and "physical fitness" "junior high school"). Diagram dibawah menunjukkan ekstraksi data dan identifikasi sesuai diagram alir prisma (Swartz, 2011).

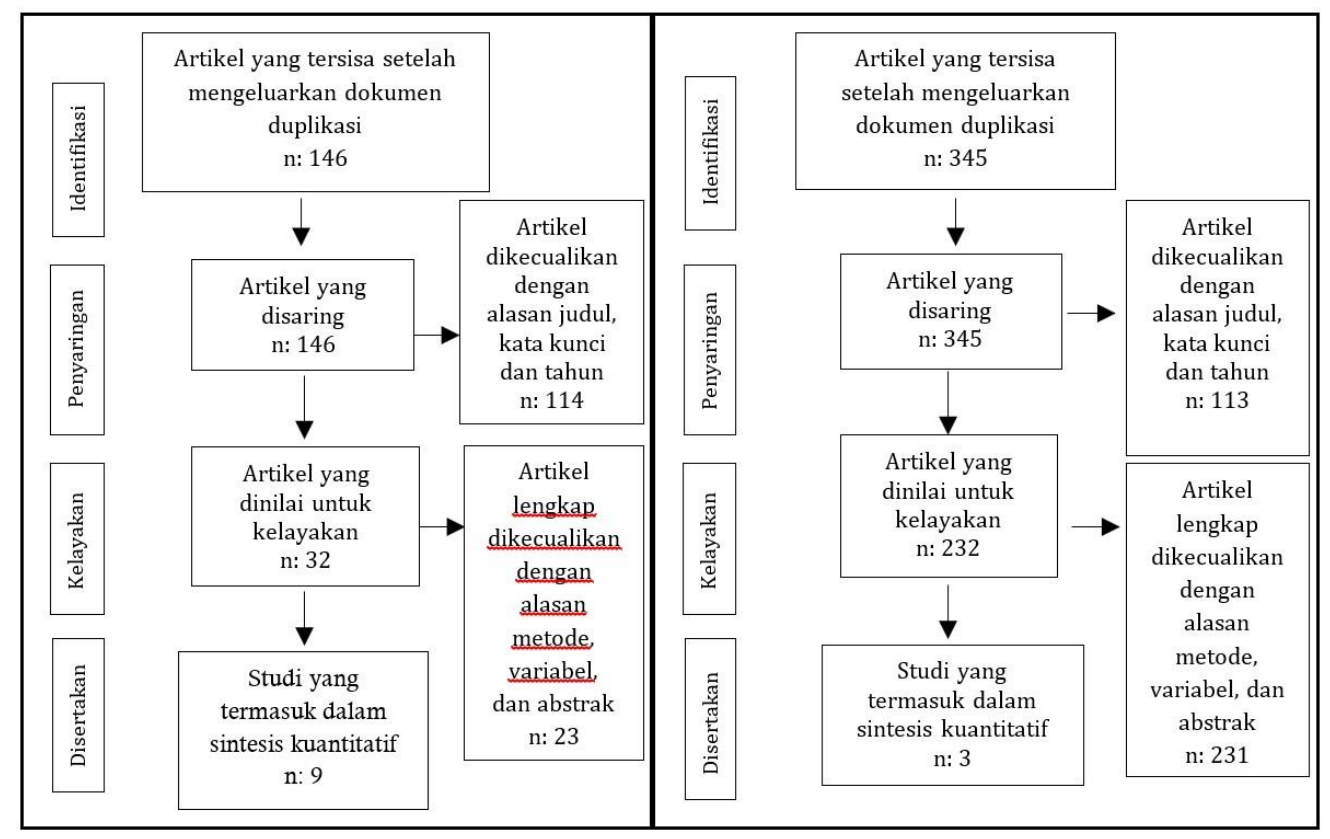

Gambar 1. Diagram Alir Prisma Ekstraksi dan Identifikasi Data.

\section{Hasil dan Pembahasan}

Hasil penelitian yang telah dianalisis untuk menjawab tujuan dari penelitian, yaitu menemukan keterkaitan antara aktivitas fisik, status gizi terhadap kebugaran jasmani berdasarkan dari data sekunder atau artikel jurnal penelitian sebelumnya. Data disajikan dari beberapa artikel sebagai berikut. 
Tabel 1. Gambaran Umum Penelitian

\begin{tabular}{|c|c|c|c|c|c|c|}
\hline $\begin{array}{l}\text { No } \\
\text {. }\end{array}$ & Penulis & $\begin{array}{l}\text { Tahu } \\
\text { n }\end{array}$ & $\begin{array}{l}\text { Rancangan } \\
\text { Penelitian }\end{array}$ & $\begin{array}{l}\text { Metode } \\
\text { Pengumpula } \\
\text { n Data }\end{array}$ & $\begin{array}{l}\text { Jumlah } \\
\text { Responden }\end{array}$ & $\begin{array}{l}\text { Desain } \\
\text { Penelitian }\end{array}$ \\
\hline 1 & Bustamam & 2017 & $\begin{array}{l}\text { Observasion } \\
\text { al }\end{array}$ & $\begin{array}{l}\text { IMT/U, Tes } \\
\text { TKJI, Angket } \\
\text { Aktivitas Fisik }\end{array}$ & 47 & $\begin{array}{l}\text { Korelasion } \\
\text { al }\end{array}$ \\
\hline 2 & $\begin{array}{l}\text { Hukubun } \\
\& \text { Souisa }\end{array}$ & 2019 & $\begin{array}{l}\text { Observasion } \\
\text { al }\end{array}$ & $\begin{array}{l}\text { IBM, Tes dan } \\
\text { Pengukuran } \\
\text { Kebugaran }\end{array}$ & 28 & $\begin{array}{l}\text { Korelasion } \\
\text { al }\end{array}$ \\
\hline 3 & $\begin{array}{l}\text { Irianto \& } \\
\text { Nurhayati }\end{array}$ & 2013 & $\begin{array}{l}\text { Observasion } \\
\text { al }\end{array}$ & $\begin{array}{l}\text { IMT/U, Tes } \\
\text { TKJI, Angket } \\
\text { Aktivitas Fisik }\end{array}$ & 47 & $\begin{array}{l}\text { Korelasion } \\
\text { al }\end{array}$ \\
\hline 4 & $\begin{array}{l}\text { Prasetyo \& } \\
\text { Winarno }\end{array}$ & 2017 & $\begin{array}{l}\text { Observasion } \\
\text { al }\end{array}$ & $\begin{array}{l}\text { TKJI, IMT/U, } \\
\text { physical } \\
\text { activity } \\
\text { questionnaire } \\
\text { for older } \\
\text { children }\end{array}$ & 54 & $\begin{array}{l}\text { Korelasion } \\
\text { al }\end{array}$ \\
\hline 5 & $\begin{array}{l}\text { Ferdianto } \\
\text { \& Prihanto }\end{array}$ & 2017 & $\begin{array}{l}\text { Observasion } \\
\text { al }\end{array}$ & $\begin{array}{l}\text { Angket } \\
\text { Aktivitas } \\
\text { Fisik, Tes } \\
\text { MFT }\end{array}$ & 37 & $\begin{array}{l}\text { Korelasion } \\
\text { al }\end{array}$ \\
\hline 6 & $\begin{array}{l}\text { Mahdiyyah } \\
\text { \& Hidayat }\end{array}$ & 2020 & $\begin{array}{l}\text { Observasion } \\
\text { al }\end{array}$ & TKJI, IMT/U & 66 & $\begin{array}{l}\text { Korelasion } \\
\text { al }\end{array}$ \\
\hline 7 & $\begin{array}{l}\text { Syampurm } \\
\text { a }\end{array}$ & 2018 & $\begin{array}{l}\text { Observasion } \\
\text { al }\end{array}$ & $\begin{array}{l}\text { Tes MFT, } \\
\text { Angket } \\
\text { Aktivitas Fisik }\end{array}$ & 67 & $\begin{array}{l}\text { Korelasion } \\
\text { al }\end{array}$ \\
\hline 8 & $\begin{array}{l}\text { Muharamd } \\
\text { a \& Effendi }\end{array}$ & 2020 & $\begin{array}{l}\text { Observasion } \\
\text { al }\end{array}$ & $\begin{array}{l}\text { The physical } \\
\text { Activity } \\
\text { Questionanair } \\
\text { e, Tes TKJI }\end{array}$ & 27 & $\begin{array}{l}\text { Korelasion } \\
\text { al }\end{array}$ \\
\hline 9 & $\begin{array}{l}\text { Zenitha \& } \\
\text { Hartoto }\end{array}$ & 2019 & $\begin{array}{l}\text { Observasion } \\
\text { al }\end{array}$ & $\begin{array}{l}\text { Tes MFT, } \\
\text { Angket } \\
\text { Aktivitas Fisik }\end{array}$ & 333 & $\begin{array}{l}\text { Korelasion } \\
\text { al }\end{array}$ \\
\hline 11 & $\begin{array}{l}\text { Morrow, } \\
\text { dkk }\end{array}$ & 2013 & $\begin{array}{l}\text { Observasion } \\
\text { al }\end{array}$ & $\begin{array}{l}\text { BMI, } \\
\text { Fitnessgram }\end{array}$ & 4621 & $\begin{array}{l}\text { Korelasion } \\
\text { al }\end{array}$ \\
\hline 12 & $\begin{array}{l}\text { Huotari, } \\
\text { dkk }\end{array}$ & 2011 & $\begin{array}{l}\text { Observasion } \\
\text { al }\end{array}$ & $\begin{array}{l}\text { Kuesioner } \\
\text { Aktivitas } \\
\text { Fisik, Tes } \\
\text { Kebugaran }\end{array}$ & $\begin{array}{l}722 \text { (Laki- } \\
\text { laki), } 803 \\
\text { (perempua } \\
\text { n) }\end{array}$ & $\begin{array}{l}\text { Korelasion } \\
\text { al }\end{array}$ \\
\hline 13 & $\begin{array}{l}\text { Spengler \& } \\
\text { Woll }\end{array}$ & 2013 & $\begin{array}{l}\text { Observasion } \\
\text { al }\end{array}$ & $\begin{array}{l}\text { MoMo } \\
\text { physical } \\
\text { activity } \\
\text { questionnaire, } \\
\text { KINDL-R- } \\
\text { Kiddo } \\
\text { questionnaire }\end{array}$ & 1828 & $\begin{array}{l}\text { Korelasion } \\
\text { al }\end{array}$ \\
\hline
\end{tabular}

Hasil analisis pada Tabel 1. tentang gambaran umum penelitian kebugaran jasmani. Jurnal penelitian adalah rentang tahun 2010 hingga 2020. Data disajikan berdasarkan artikel yang menunjukkan hubungan hubungan dari variabel yang diperlukan. Jumlah sampel yang 
diteliti beragam dari 28-1828 responden. Pengambilan sampel penelitian rata-rata menggunakan teknik purposive sampling dan cluster sampling. Metode pengumpulan data ratarata menggunakan tes kebugaran jasmani, dan pengukuran, IMT/U, dan kuesioner aktivitas fisik. Komponen tes kebugaran jasmani berupa tes lari cepat $50 \mathrm{~m}$, lari jauh $(1000 / 800 \mathrm{~m})$, loncat tegak, tes lari multitahap, bleep test, baring duduk, gantung angkat tubuh dan pengukuran menggunakan fitnessgram.

Dari artikel dapat diketahui interaksi antar variabel. Terdapat 3 artikel yang tidak menunjukkan hubungan signifikan antara aktivitas fisik terhadap kebugaran jasmani (Cocca, Baca, Cruz, \& Cocca, 2020; Jegatheesan et al., 2021; Orland et al., 2021; Pacífico et al., 2018). Kebugaran jasmani dapat dipengaruhi oleh berbagai faktor. Faktor yang mempengaruhi kebugaran jasmani bisa berupa umur, jenis kelamin, genetik, asupan makanan, kebiasaan beraktivitas.

Tabel 2. Identifikasi Interaksi Antar Variabel

\begin{tabular}{|c|c|c|c|c|c|c|c|c|c|c|c|c|c|}
\hline \multirow[t]{2}{*}{ Variabel } & \multicolumn{13}{|c|}{ Kebugaran Jasmani } \\
\hline & 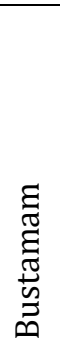 & 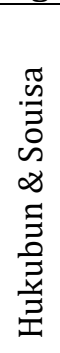 & 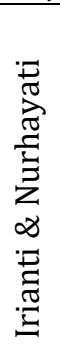 & 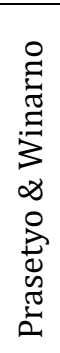 & 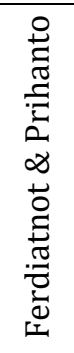 & 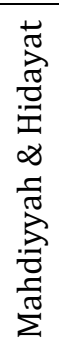 & 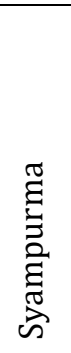 & 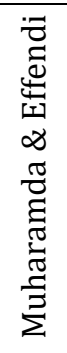 & 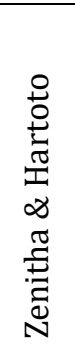 & $\begin{array}{l}3 \\
0 \\
0 \\
0_{0}^{3}\end{array}$ & $\begin{array}{l}\overline{\tilde{J}} \\
\stackrel{0}{0} \\
\stackrel{9}{9}\end{array}$ & $\begin{array}{l}\overline{0} \\
\vdots \\
\infty \\
\dot{0} \\
\overline{0} \\
\overline{0} \\
\tilde{0}\end{array}$ & $\begin{array}{l}\underset{\pi}{\tilde{0}} \\
\stackrel{0}{\bullet}\end{array}$ \\
\hline Aktivitas Fisik & $\sqrt{ }$ & & $\sqrt{ }$ & $\sqrt{ }$ & $\sqrt{ }$ & & $\sqrt{ }$ & $\sqrt{ }$ & $\sqrt{ }$ & $\sqrt{ }$ & $\sqrt{ }$ & $\sqrt{ }$ & 10 \\
\hline Status Gizi & $\sqrt{ }$ & $\sqrt{ }$ & $\sqrt{ }$ & $\sqrt{ }$ & & $\sqrt{ }$ & & & & & & & 5 \\
\hline
\end{tabular}

\subsection{Status Gizi dengan Kebugaran Jasmani}

Angka kecukupan gizi memberikan pengaruh pada pertumbuhan dan perkembangan remaja. Kecukupan gizi remaja dapat mengatur metabolisme tubuh, memelihara, dan mendukung sistem mekanisme tubuh. Asupan gizi yang sesuai menjadi energi untuk melakukan berbagai aktivitas fisik sehingga dapat digunakan untuk membentuk, meningkatkan, dan memelihara kebugaran jasmani. Status gizi merupakan gambaran mengenai keseimbangan tubuh menerima zat gizi dengan yang diperlukan oleh tubuh. Hasil penelitian melaporkan status gizi berhubungan terhadap kebugaran jasmani (Cocca, Verdugo, Cuenca, \& Cocca, 2020; Oppewal \& Hilgenkamp, 2020; Páez-Maldonado et al., 2020; Rodriguez, de Camargo, Rodriguez-Añez, \& Reis, 2020; Sampaio et al., 2020; Wouters, Evenhuis, \& Hilgenkamp, 2020). Kebutuhan zat gizi remaja laki-laki berbeda dengan perempuan, penyebab dari kekurangan gizi disebabkan oleh pola makan yang tidak seimbang. Perempuan lebih mengutamakan menjaga berat badan agar tetap proporsional sehingga tidak cukup banyak zat gizi yang masuk. Sedangkan laki-laki cenderung lebih banyak asupan energi secara tidak sadar telah memenuhi zat gizi yang diperlukan oleh tubuh. Remaja laki-laki mengalami peningkatan lebih pesat daripada perempuan pada aspek tinggi, berat badan, lean body mass sehingga membutuhkan energi lebih besar daripada perempuan (Purnama, 2019). Kebutuhan energi juga dapat ditentukan dari aktivitas fisiknya, apabila intensitas aktivitas fisik semakin besar maka semakin besar energi yang dibutuhkan. Proporsi kebutuhan gizi seseorang berbeda yang ditentukan oleh usia, berat badan, jenis kelamin, aktivitas fisik, kondisi lingkungan seperti suhu 
dan keadaan tertentu misalnya sakit, ibu hamil dan menyusui (Sefaya, Nugraheni, \& Pangestuti, 2017).

Mengonsumsi makanan memiliki pengaruh pada status gizi. Status gizi yang baik akan mendukung hasil kebugaran jasmani. Status gizi dalam kategori baik apabila memperoleh cukup zat gizi yang bisa digunakan oleh tubuh untuk membantu pertumbuhan fisik, perkembangan daya pikir, keaktifan, dan kesehatan secara umum. Status gizi kurang apabila tubuh menerima zat gizi dalam kapasitas yang berlebihan sehingga menimbulkan efek negatif dan membahayakan bagi tubuh. Kebutuhan energi ditentukan oleh metabolisme basal, umur, aktivitas fisik, suhu, lingkungan, serta kesehatan, dan dianjurkan jumlah energi diperoleh dari 50-60\% karbohidrat, 25-35\% protein, dan 10-15\% lemak (Tangke, Katiandagho, \& Rochmady, 2020). Berikut disajikan tabel angka kecukupan gizi.

Tabel 3. Angka Kecukupan Gizi (Hikma Padaunga \& Mukarramah, 2020)

\begin{tabular}{lll}
\hline Zat Gizi & \multicolumn{2}{l}{ Laki-laki } \\
& Usia 13-15 tahun \\
\hline Energi & $2400 \mathrm{kkal}$ & $2050 \mathrm{kkal}$ \\
Protein & $70 \mathrm{~g}$ & $65 \mathrm{~g}$ \\
Lemak & $80 \mathrm{~g}$ & $70 \mathrm{~g}$ \\
Karbohidrat & $350 \mathrm{~g}$ & $300 \mathrm{~g}$ \\
Serat & $34 \mathrm{~g}$ & $29 \mathrm{~g}$ \\
Air & $2100 \mathrm{ml}$ & $2100 \mathrm{ml}$ \\
\hline
\end{tabular}

Menurut Dwi Jayanti \& Elsa Novananda, (2019) faktor yang berhubungan dengan gizi remaja disebabkan pendapatan keluarga, pola diet, masalah Kesehatan, kekurangan gizi, pola gizi yang berlebihan, pertumbuhan fisik, pengetahuan dan Pendidikan, kebebasan, aspek waktu, aspek keuangan. Pendapatan keluarga menentukan kebutuhan, secara umum pendapatan keluarga tinggi terdapat potensi untuk memperhatikan pola makan tiap anggota keluarga. Demikian, pendapatan tinggi tidak menjamin bahwa status gizi akan seimbang, maka perlu adanya pengetahuan gizi tidak hanya terbatas mampu membeli makanan. Silalahi dkk., (2016) menemukan bahwa terdapat perbedaan yang bermakna skor pengetahuan gizi diantara sebelum dan sesudah intervensi. Hasil lain tidak terdapat perbedaan yang bermakna asupan gizi diantara sebelum dan sesudah intervensi. Hasil ini dipengaruhi oleh ketersediaan pangan, pendapatan dan pengetahuan orangtua. Selanjutnya intervensi Pendidikan pada orangtua mengenai pemenuhan gizi memberikan peran penting terhadap status gizi remaja.

\subsection{Aktivitas Fisik dengan Kebugaran Jasmani}

Kebugaran jasmani pada remaja tidak hanya dipengaruhi oleh status gizi, tetapi juga pada aktivitas fisik. Berdasarkan pengukuran tingkat kebugaran jasmani menunjukkan aktivitas keseharian dapat mempengaruhi kualitas dari kebugaran jasmani. Kebugaran jasmani siswa dapat diprediksi melalui aktivitas fisik dapat diukur dengan berat badan, tinggi badan, umur, jenis kelamin (Sulistiono, 2014). Penelitian melaporkan terdapat hubungan antara aktivitas fisik terhadap kebugaran jasmani (Syampurma, 2018) (Muharamda \& Effendi, 2020) (Zenitha \& Hartoto, 2019) (Prasetyo \& Winarno, 2017). Berdasarkan data yang diperoleh aktivitas fisik memiliki sumbangan lebih besar daripada status gizi. Kecenderungan tidak terlibat aktif dalam keseharian remaja mengakibatkan rendahnya parameter kebugaran jasmani. Sedangkan, salah satu penelitian melaporkan tidak terdapat hasil yang signifikan antara aktivitas fisik terhadap kebugaran jasmani (Suryadinata, Wirjatmadi, Adriani, \& Lorensia, 2020). Hasil ini dapat dipengaruhi oleh faktor lain. Wiarto (2013) mengungkapkan 
tingkat kebugaran jasmani dipengaruhi oleh faktor usia, jenis kelamin, genetik, makanan, merokok. Faktor genetik dapat berpengaruh pada kapasitas jantung-paru, postur tubuh, obesitas, hemoglobin, dan serat otot.

Semakin baik aktivitas fisik siswa maka semakin meningkat kebugaran jasmani siswa. Kedua variabel aktivitas fisik dan status gizi memberikan sumbangan bermakna terhadap kebugaran jasmani. Berdasarkan data yang diperoleh aktivitas fisik memiliki sumbangan lebih besar daripada status gizi. Aktivitas fisik dengan durasi tidak cukup serta pelaksanaan yang tidak berkualitas maka sulit untuk memberikan perubahan pada tingkat kebugaran jasmani, sehingga menjadi pemicu obesitas atau kelebihan berat badan pada masa remaja. Pengendalian kebugaran fisik mengurangi dampak kelebihan berat badan pada Health Related Quality of Life (HRQOL), upaya mempromosikan aktivitas fisik perlu adanya (Morales dkk., 2013). Tingkat kebugaran jasmani yang baik memungkinkan anak dapat aktif secara fisik, selain itu berpengaruh pada kualitas hidup terutama manfaatnya terhadap kelebihan berat badan.

Pelatihan menyebabkan peningkatan yang signifikan pada parameter kebugaran jasmani meskipun tidak terbukti mengenai perbedaan hasil dari High Intensity Interval (HIT) dengan Continuous Training (CT) (Kramps \& Lane-Cordova, 2021). Dukungan orangtua dan kelas sosial berhubungan positif dengan aktivitas fisik pada remaja (Raudsepp, 2006). Partisipasi aktivitas fisik yang sifatnya lebih besar di dalam klub olahraga memerlukan dukungan dari orangtua untuk mempromosikan, mendorong, dan memberikan dukungan di klub olahraga (Hnatiuk, Dwyer, George, \& Bennie, 2020).

Sangat diperlukan aktivitas berupa olahraga kesehatan yang dianjurkan. Tujuan olahraga kesehatan adalah untuk memelihara dan meningkatkan derajat kesehatan. Olahraga kesehatan merupakan bentuk upaya yang sifatnya preventif dan promotif untuk mencegah penurunan fungsi tubuh maupun untuk meningkatkan derajat kesehatan. Menurut Ardella, (2020) aktivitas fisik di usia 12-18 tahun setidaknya 60 menit perhari dengan intensitas sedang hingga kuat. Aktivitas sedang dapat berupa berjalan cepat, bersepeda dengan teman, bermain skateboard dan menari. Sedangkan aktivitas berat berupa bermain sepakbola, permainan netball, lari, berenang, latihan olahraga. Apabila dikehendaki kesehatan tambahan dapat dilakukan 20 menit atau lebih untuk 3-4 hari seminggu. Variasi aktivitas sangat penting untuk memberikan pengalaman menyenangkan, tantangan, dan kesempatan mempelajari keterampilan baru.

\section{Simpulan}

Aktivitas fisik menunjukkan berhubungan terhadap kebugaran jasmani siswa. Status kebugaran jasmani dapat didukung oleh asupan gizi yang seimbang, hal tersebut telah dibuktikan bahwa status gizi juga berhubungan terhadap kebugaran jasmani. Keseimbangan status gizi memberikan pengaruh pada kebugaran jasmani. Pola makan dan asupan zat gizi yang tidak tepat akan menyebabkan masalah gizi pada remaja. Terdapat faktor-faktor yang mempengaruhi pencapaian status gizi baik seperti pendapatan keluarga, pengetahuan orangtua mengenai gizi, masalah kesehatan individu, pertumbuhan fisik. Terdapat hasil tidak signifikan antara aktivitas fisik terhadap kebugaran jasmani yang disebabkan oleh faktorfaktor tertentu, seperti usia, jenis kelamin, genetik, aktivitas. Aktivitas fisik dengan durasi dan pelaksanaan tidak berkualitas maka sulit untuk memberikan perubahan terhadap kebugaran 
jasmani. Kebugaran jasmani yang baik memungkinkan aktif secara fisik, hal tersebut berdampak positif terhadap kualitas hidup dan kesehatan.

\section{Daftar Rujukan}

Ardella, K. B. (2020). Risiko Kesehatan Akibat Perubahan Pola Makan Dan Tingkat Aktivitas Fisik Selama Pandemi Covid-19. Jurnal Medika Hutama, 2(1), 292-297.

Bush, C. L., Blumberg, J. B., El-Sohemy, A., Minich, D. M., Ordovás, J. M., Reed, D. G., \& Behm, V. A. Y. (2020). Toward the Definition of Personalized Nutrition: A Proposal by The American Nutrition Association. Journal of the American College of Nutrition, Vol. 39, pp. 5-15. https://doi.org/10.1080/07315724.2019 .1685332

Caldwell, H. A. T., Di Cristofaro, N. A., Cairney, J., Bray, S. R., Macdonald, M. J., \& Timmons, B. W. (2020). Physical literacy, physical activity, and health indicators in school-age children. International Journal of Environmental Research and Public Health, 17(15), 1-12. https://doi.org/10.3390/ijerph17155367

Cocca, A., Baca, J. E. C., Cruz, G. H., \& Cocca, M. (2020). Does a multiple-sport intervention based on the TGFU pedagogical model for physical education increase physical fitness in primary school children? International Journal of Environmental Research and Public Health, 17(15), 1-11. https://doi.org/10.3390/ijerph17155532

Cocca, A., Verdugo, F. E., Cuenca, L. T. R., \& Cocca, M. (2020). Effect of a game-based physical education program on physical fitness and mental health in elementary school children. International Journal of Environmental Research and Public Health, 17(13), 1-13. https://doi.org/10.3390/ijerph17134883

Dwi Jayanti, Y., \& Elsa Novananda, N. (2019). Hubungan Pengetahuan Tentang Gizi Seimbang Dengan Status Gizi Pada Remaja Putri Kelas Xi Akuntansi 2 (Di Smk Pgri 2 Kota Kediri). Jurnal Kebidanan, 6(2), 100108. https://doi.org/10.35890/jkdh.v6i2.38

El-Sherif, J. L. (2014). Student Voice: Student Choice and Participation in Physical Education. Strategies, 27(5), 8-11. https://doi.org/10.1080/08924562.2014.938875

Hikma Padaunga, A., \& Mukarramah, S. (2020). Hubungan Angka Kecukupan Zat Besi Dan Vitamin C Dengan Kejadian Anemia Pada Ibu Hamil. Media Ilmu Kesehatan, 8(2), 147-154. https://doi.org/10.30989/mik. v8i2.307

Hnatiuk, J. A., Dwyer, G., George, E. S., \& Bennie, A. (2020). Co-participation in physical activity: Perspectives from Australian parents of pre-schoolers. Health Promotion International, 35(6), 1474-1483. https://doi.org/10.1093/heapro/daaa022

Ho, F., Louie, L., Wong, W., Chan, K. L., Tiwari, A., Chow, C. B., ... al., et. (2018). A sports mentorship program improves adolescent mental health and physical fitness: a randomised controlled trial. Hong Kong Journal of Paediatrics, 23(1), 88-89. Retrieved from https://www.cochranelibrary.com/central/doi/10.1002/central/CN-01462413/full

Jegatheesan, D. K., Modderman, R., Krishnasamy, R., Tong, A., Coombes, J. S., Viecelli, A. K., ... Isbel, N. (2021). A Systematic Review of Scope and Consistency of Outcome Measures for Physical Fitness in Chronic Kidney Disease Trials. Kidney International Reports, 6(5), 1280-1288. https://doi.org/10.1016/j.ekir.2021.02.010

Kanca, I. N. (2018). Menjadi Guru Pendidikan Jasmani Olahraga dan Kesehatan di Abad 21. Prosiding Seminar Nasional IPTEK Olahraga, 21-27.

Kramps, K., \& Lane-Cordova, A. (2021). High-intensity interval training in cardiac rehabilitation. Sport Sciences for Health, Vol. 17, pp. 269-278. https://doi.org/10.1007/s11332-021-00731-0

Lavin, J. (2008). Creative Approaches to Physical Education: Helping Children to Achieve Their True Potential. New York: New York: Routledge.

Lisa, M., Philip, J., Beurden, V., \& David, R. (2011). A Reverse Pathway? Actual and Perceived Skill Proficiency and Physical Activity. Journal Medicine \& Sciences \& Exercise, 43(5), 898-904.

Lumpkin, A. (2014). Introduction Physical Education, Exercise Science, and Sport. New York: New York: McGrawHill Education.

Mahdiyyah, A. N., \& Hidayat, T. (2020). Hubungan Antara Status Gizi Dengan Kebugaran Jasmani Siswa Kelas Ix Smp Negeri 2 Buduran. Jurnal Pendidikan Olahraga Dan Kesehatan, 8(1), 105-109.

Mashud, M. (2018). Analisis Masalah Guru PJOK Dalam Mewujudkan Tujuan Kebugaran Jasmani. Multilateral Jurnal Pendidikan Jasmani Olahraga, 17(2), 77-85. 
Morales, P. F., Sánchez-López, M., Moya-Martínez, P., García-Prieto, J. C., Martínez-Andrés, M., García, N. L., \& Martínez-Vizcaíno, V. (2013). Health-Related Quality of Life, Obesity, and Fitness in Schoolchildren: The Cuenca study. Quality of Life Research, 22(7), 1515-1523. https://doi.org/10.1007/s11136-012-02828

Muharamda, M. \& Effendi, H. (2020). Konstribusi Aktivitas Fisik terhadap Kebugaran Jasmani Siswa SMPN 4 Lembah Gumanti. Journal of Chemical Information and Modeling, 53(9), 1689-1699. https://doi.org/10.1017/CB09781107415324.004

Oppewal, A., \& Hilgenkamp, T. I. M. (2020). Adding meaning to physical fitness test results in individuals with intellectual disabilities. Disability and Rehabilitation, 42(10), 1406-1413. https://doi.org/10.1080/09638288.2018.1527399

Orland, Y., Beeri, M. S., Levy, S., Israel, A., Ravona-Springer, R., Segev, S., \& Elkana, O. (2021). Physical fitness mediates the association between age and cognition in healthy adults. Aging Clinical and Experimental Research, 33(5), 1359-1366. https://doi.org/10.1007/s40520-020-01621-0

Pacífico, A. B., de Camargo, E. M., de Oliveira, V., Vagetti, G. C., Piola, T. S., \& de Campos, W. (2018). Comparison of physical fitness and quality of life between adolescents engaged in sports and those who are not. Revista Brasileira de Cineantropometria E Desempenho Humano, 20(6), 544-554. https://doi.org/10.5007/1980-0037.2018v20n6p544

Páez-Maldonado, J. A., Reigal, R. E., Morillo-Baro, J. P., Carrasco-Beltrán, H., Hernández-Mendo, A., \& MoralesSánchez, V. (2020). Physical fitness, selective attention, and academic performance in a pre-adolescent sample. International Journal of Environmental Research and Public Health, 17(17), 1-11. https://doi.org/10.3390/ijerph17176216

Pangrazi, R. P., \& Beighle, A. (2019). Dynamic Physical Education for Elementary School Children (Eighteenth). Arizona: Arizona: Arizona State University.

Permendiknas No 22. (2006). Peraturan Menteri Pendidikan Nasional Republik Indonesia Nomor 22 Tahun 2006 Tentang Standar Isi Untuk Satuan Pendidikan Dasar Dan Menengah (Vol. 122, pp. 1-48). Vol. 122, pp. 148.

Prasetyo, A., \& Winarno, M. E. (2017). Hubungan Antara Status Gizi Dan Aktivitas Fisik Dengan Tingkat Kebugaran Jasmani Siswa. Jurnal Pendidikan Olahraga Dan Kesehatan, 4(2), 516-521.

Purnama, N. L. A. (2019). Perilaku Makan dan Status Gizi Remaja. Jurnal Penelitian Kesehatan, 9(2), 57-62.

Rahayu, T. B. (2020). Analisis Faktor-Faktor Yang Mempengaruhi Status Gizi Remaja Putri. Jurnal Vokasi Kesehatan, 6(1), 46. https://doi.org/10.30602/jvk.v6i1.158

Raudsepp, L. (2006). The Relationship between Socio-Economic Status, Parental Support and Adolescent Physical Activity. Acta Paediatrica, International Journal of Paediatrics, 95(1), 93-98. https://doi.org/10.1080/08035250500323772

Rodriguez, C. C., de Camargo, E. M., Rodriguez-Añez, C. R., \& Reis, R. S. (2020). Physical activity, physical fitness and academic achievement in adolescents: A systematic review. Revista Brasileira de Medicina Do Esporte, 26(5), 441-448. https://doi.org/10.1590/1517-8692202026052019_0048

Sampaio, A., Marques-Aleixo, I., Seabra, A., Mota, J., Marques, E., \& Carvalho, J. (2020). Physical fitness in institutionalized older adults with dementia: association with cognition, functional capacity and quality of life. Aging Clinical and Experimental Research, 32(11), 2329-2338. https://doi.org/10.1007/s40520019-01445-7

Sceisarriya, V. M. (2017). Problematika pelaksanaan Pendidikan Jasmani di Sekolah Dasar. Seminar Nasional Pendidikan Olahraga, 1(1), 167-173.

Sefaya, K., Nugraheni, S., \& Pangestuti, D. (2017). Pengaruh Pendidikan Gizi Terhadap Pengetahuan Gizi Dan Tingkat Kecukupan Gizi Terkait Pencegahan Anemia Remaja (Studi Pada Siswa Kelas Xi Sma Teuku Umar Semarang. Jurnal Kesehatan Masyarakat (E-Journal), 5(1), 272-282.

Shimon, J. M. (2011). Teaching Physical Education Principles and Strategies. New York: New York:United States of America.

Silalahi, V., Aritonang, E., \& Ashar, T. (2016). Potensi Pendidikan Gizi dalam Meningkatkan Asupan Gizi pada Remaja Putri Yang Anemia di Kota Medan. Jurnal Kesehatan Masyarakat, 11(2), 295. https://doi.org/10.15294/kemas.v11i2.4113

Sucipto, S. (2019). The Implementation of Tactical Approach on Students' Enjoyment in Playing Football in Junior High School. Jurnal Pendidikan Jasmani dan Olahraga, 4(1), 14-20. 
Sport Science and Health, 4(1), 2022, 1-11

Sulistiono, A. A. (2014a). Kebugaran Jasmani Siswa Pendidikan Dasar dan Menengah di Jawa Barat. Jurnal Pendidikan Dan Kebudayaan, 20 no 2, 223-233.

Sulistiono, A. A. (2014b). Prediksi Aktivitas Fisik Sehari-Hari, Umur, Tinggi, Berat Badan Dan Jenis Kelamin Terhadap Kebugaran Jasmani Siswa Smp Di Banjarmasin. Jurnal Pendidikan Dan Kebudayaan, 20(September), 381.

Suryadinata, R. V., Wirjatmadi, B., Adriani, M., \& Lorensia, A. (2020). Effect of age and weight on physical activity. Journal of Public Health Research, 9(2), 187-190. https://doi.org/10.4081/jphr.2020.1840

Susilowati, K. (2016). Gizi dalam daur kehidupan. PT Refika Aditama: Bandung.

Swartz, M. K. (2011). The PRISMA Statement: A Guideline for Systematic Reviews and Meta-analyses. Journal of Pediatric Health Care, 25(1), 1-2.

Syampurma, H. (2018). Hubungan Aktivitas Fisik dengan Kebugaran Jasmani pada Siswa Sekolah Menengah Pertama Bertaraf Internasional Kota Padang. Jurnal Sport Science, 18(1), 55-65.

Tangke, U., Katiandagho, B., \& Rochmady, R. (2020). Nutritional Adequacy Rate (RDA) and Nutritional Value Information (ING) of Tuna Kering Kayu Fish Canned with Tuna Fish Bone Flour Substitution. Agrikan: Jurnal Agribisnis Perikanan, 13(2), 352-357. https://doi.org/10.29239/j.agrikan.13.2.352-357

Undang-undang No 3. (2005). Undang-Undang Republik Indonesia Nomor 3 Tahun 2005 Tentang Sistem Keolahragaan Nasional Dengan. Presiden RI, pp. 1-53.

Wiarto, G. (2013). Fisiologi dan Olahraga. Yogyakarta: Graha Ilmu.

Wouters, M., Evenhuis, H. M., \& Hilgenkamp, T. I. M. (2020). Physical fitness of children and adolescents with moderate to severe intellectual disabilities. Disability and Rehabilitation, 42(18), 2542-2552. https://doi.org/10.1080/09638288.2019.1573932

Zenitha, N. M., \& Hartoto, S. (2019). Hubungan Aktivitas Fisik Diluar Jam Pelajaran Pjok Terhadap Tingkat Kebugaran Jasmani Siswa. Jurnal Pendidikan Olahraga Dan Kesehatan, 7(3), 519-522. 